\title{
Fractured zygomatic arch: a traumatic cause for trismus
}

\author{
Karim Kassam, ${ }^{1}$ Ashraf Messiha ${ }^{2}$
}

${ }^{1}$ Department of Maxillofacial Surgery, Northwest London Hospitals, London, UK ${ }^{2}$ Department of Oral \& Maxillofacial Surgery, Northwick Park Hospital, London, UK

\section{Correspondence to} Karim Kassam, kkassam7860@hotmail.com

Accepted 10 November 2013

\section{DESCRIPTION}

We report a case of a patient with a 9-day history of trismus measured at $9 \mathrm{~mm}$ (figure 1). The trismus occurred immediately after an alleged assault with punch injuries to the face. Note the flattening of the malar process on the left hand side of the face. $\mathrm{X}$-rays of the facial bones showed a depressed fracture of the zygomatic arch with a medial rotation of the zygomatic complex (figure 2). Orthopantogram $\mathrm{X}$-ray clearly showed an additional fracture of the coronoid process (figure 3). Clinically, the depressed arch fracture has impinged on the coronoid process producing the limitation in mouth opening. The Henderson Classification is a commonly used system to describe zygomatic fractures. It ranges from Henderson I, which is an undisplaced fracture at any site, to Henderson VII, which is a

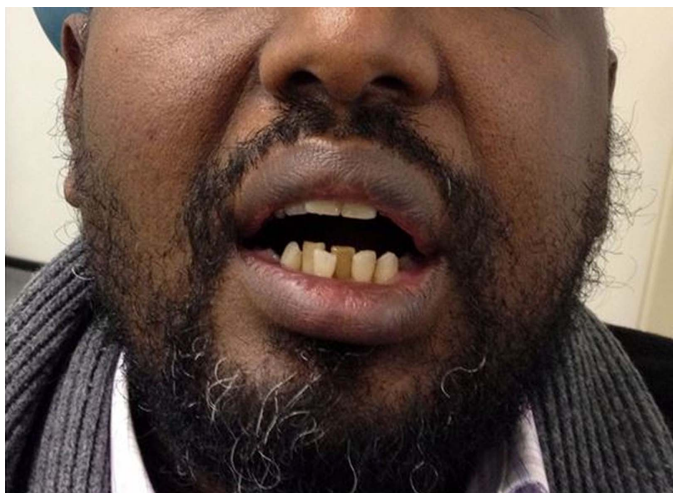

Figure 1 Trismus secondary to depressed zygomatic arch fracture.

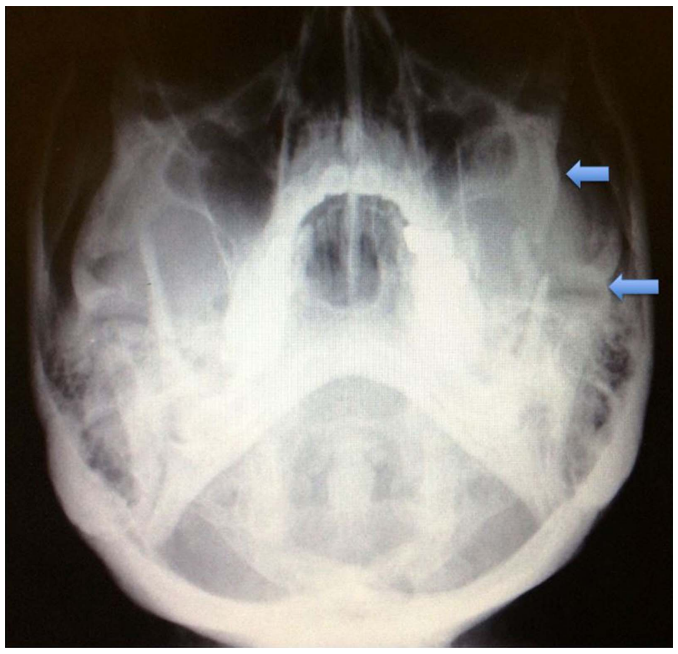

Figure 2 Occipitomental X-ray illustrating two fractures in the left zygomatic arch. comminuted fracture. This is a case of Henderson IV type, as it is a tripod fracture with a distracted frontozygomatic suture which could also be palpated clinically. There is a high probability that the conservative treatment in this case would lead to temporomandibular pseudoankylosis characterised by trismus-restricted mandibular movements, resulting from factors outside the joint. Treatment will involve elevation of the arch with a two-point fixation at the zygomatic buttress placed via an intraoral approach and at the frontozygomatic suture placed via an upper blepharoplasty incision. The fractured coronoid can be removed if unstable and preventing mouth-opening or quite often left due to its strong muscle attachments. The operation will restore the mouth-opening and improve the cosmetic defect (figure 4).

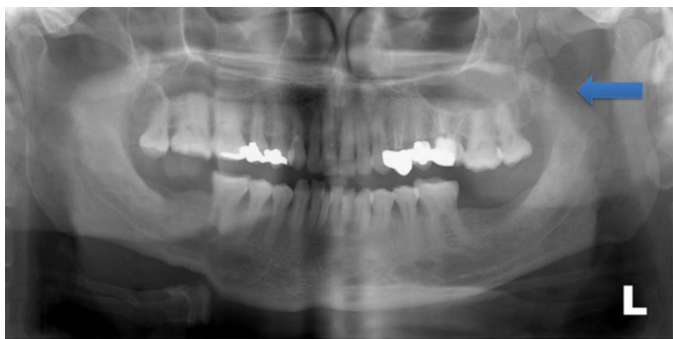

Figure 3 Orthopantogram showing fracture of the coronoid process of the mandible.

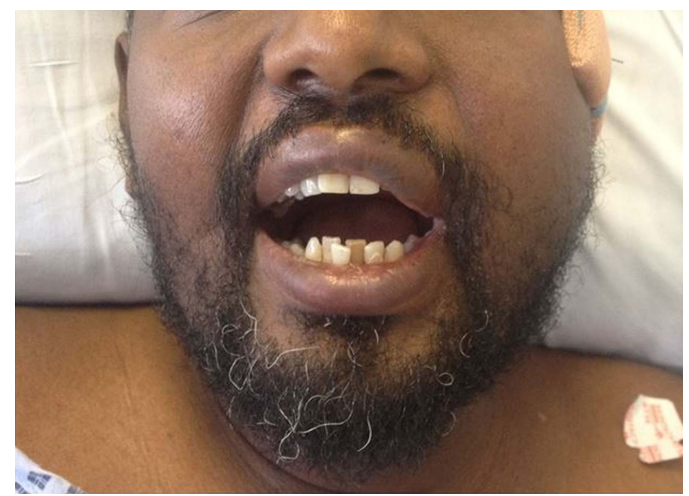

Figure 4 Postoperative photograph showing immediate improvement in mouth opening. Sutures have been passed around the arch transcutaneously and then around a finger splint to stabilise the arch. 


\section{Learning points}

- A depressed zygomatic arch can be a cause of trismus in the trauma setting.

- X-rays of the facial bones are useful in diagnosis of the patient presenting with trismus.

- If treated conservatively, it can lead to pseudoankylosis of the temporomandibular joint and lifelong trismus.
Competing interests None.

Patient consent Obtained.

Provenance and peer review Not commissioned; externally peer reviewed.

Copyright 2014 BMJ Publishing Group. All rights reserved. For permission to reuse any of this content visit http://group.bmj.com/group/rights-licensing/permissions.

BMJ Case Report Fellows may re-use this article for personal use and teaching without any further permission.

Become a Fellow of BMJ Case Reports today and you can:

- Submit as many cases as you like

- Enjoy fast sympathetic peer review and rapid publication of accepted articles

- Access all the published articles

- Re-use any of the published material for personal use and teaching without further permission

For information on Institutional Fellowships contact consortiasales@bmjgroup.com

Visit casereports.bmj.com for more articles like this and to become a Fellow 